\title{
ATLANTIC MIDSHIPMAN, PORICHTHYS PLECTRODON, IN NORTH CAROLINA
}

\author{
FRANK J. SCHWARTZ \\ University of North Carolina \\ Institute of Marine Science \\ 3431 Arendell Street \\ Morehead City, NC, 28557-3209 \\ Email: fjs@email.unc.edu
}

\begin{abstract}
A total of 2,910 Atlantic midshipman were collected, mainly by trawl, off North Carolina between 1911-2012. Only four were found in Pamlico Sound. Once abundant their numbers have declined after 1990 when ocean water temperatures changed from cool to warm. Today they are rarely caught or seen in North Carolina.
\end{abstract}

\section{INTRODUCTION}

Gilbert (1968) reviewed the western Atlantic midshipman genus Porichthys, family Batrachoididae, Jordan (1919) and Hubbs and Schultz (1939) had placed Porichthys in the genus Nautopaedium that Gilbert (1968) considered a synonym of Porichthys. Porichthys porosissimus (Valenciennes 1879), that originally ranged from Virginia, Gulf of Mexico to Northern Brazil, was found to be comprised of five species: P. plectrodon (Jordan and Gilbert, 1882) that ranges from Virginia, Gulf of Mexico to Northern Brazil: $P$. bathkeas (Gilbert, 1968) that ranges from the Western Caribbean, and Honduras to Colombia: P. pauciradiatus Caldwell and Caldwell 1963 that ranges from Costa Rica, Panama, to Northern Brazil; P. oculofrenum Gilbert, 1968 that ranges Venzuela to Northern Brazil and P. kymosemeum Gilbert 1968 that is known only from the mouth of the Amazon. P. pororissimus now occurs from southern Brazil and Argentina (Collette 2002).

P. plectrodon is a $218 \mathrm{~mm}$ total length (TL) elongate fish possessing long dorsal and anal fins and four distinct rows of photophores (light emitting organs) along the body, head and throat. Photophores found on the throat form a distinct "U." Midshipman are found over mud and sand substrates down to $206 \mathrm{~m}$ depths (McEachran and Fechhem 1989). This report treats distributions, sizes, occurrences of 2,910 midshipmen collected in North Carolina waters 1911-2012 and why they are rarely caught or seen today (Schwartz 2012).

\section{STUDY AREA}

North Carolina (Fig. 1) extends from approximately $32^{\circ} 20^{\prime} \mathrm{N}$ to $36^{\circ} 31^{\prime} \mathrm{N}$. Its Continental Shelf is narrow at Cape Hatteras (16 km wide) and about $73 \mathrm{~km}$ wide off Morehead City and Wilmington, North Carolina. Ocean depths vary from the shore to the Continental Shelf edge (200 m); salinities vary 34-36 0/00; tides are less than $1 \mathrm{~m}$; water temperatures range $10-35^{\circ} \mathrm{C}$; substrates vary from sandy shore to sandy-mud and rocky reefs at the Continental Shelf edge. Currents are influenced southerly along the shore and northerly offshore by the Gulf Stream. Nearby, $80 \times 40 \mathrm{~km}$ long Pamlico Sound; depths range 1-7 m; salinities 0-32 0/00 (Schwartz and Chestnut 1973); tides are less than $1 \mathrm{~m}$ and substrates are mostly muddy. The Cape Fear estuary enters the ocean at Southport, North Carolina; salinities vary $0-32 / 00$, tides are $\pm 2 \mathrm{~m}$; substrates are sandy-mud and water temperatures range $2-32^{\circ} \mathrm{C}$ (Schwartz et al. 1978).

\section{METHODS}

Otter trawl surveys (1992-1999) by the WHOI (Woods Hole Oceanographic Institute) caught 2,507 midshipman (Wigley et al. 2003); IMS 171; R/V Dan Moore 38 and 38 by fly net trawls Bullis and Thompson R/V Silver Bay 48; Schwartz and Porter, scallop grounds 11; Gilbert (1986) (16); Cape Fear area 11; USNM 3 and 63 others in the ocean, Pamlico sound (4) and the Cape Fear estuary. Only 171 midshipman, now at the NCSM, Raleigh, NC were measured (standard length SL and total length TL). The formula $\log y=a+b \log x$ was used to convert SL to TL and TL to SL.

\section{OBSERVATIONS}

WHOI-_Annual (WHOI) trawl surveys (1992-1999) collected 2,507 Atlantic midshipman at 263 localities between $33^{\circ} 21^{\prime} \mathrm{N}$ and $36^{\circ} 10^{\prime} \mathrm{N}$ (Fig. 1). Fall surveys collected 1,952 (77.9\%) midshipman versus 251 in Spring (10.01\%) and 304 (12.5\%) during summer sampling of $1-1,302 \mathrm{~m}$ ocean depths, the maximum depth midshipman were captured was $302 \mathrm{~m}$, occurring 4 March 1984 , at $33^{\circ} 07^{\prime} \mathrm{N}, 76^{\circ} 20^{\prime} \mathrm{W}$. Trawling efforts were greatest during the months of May (15 trips), November (27) and March (127) dominating.

IMS.-One hundred seventy-one Atlantic Midshipmen were collected at 71 stations (69 ocean, 2 Pamlico 


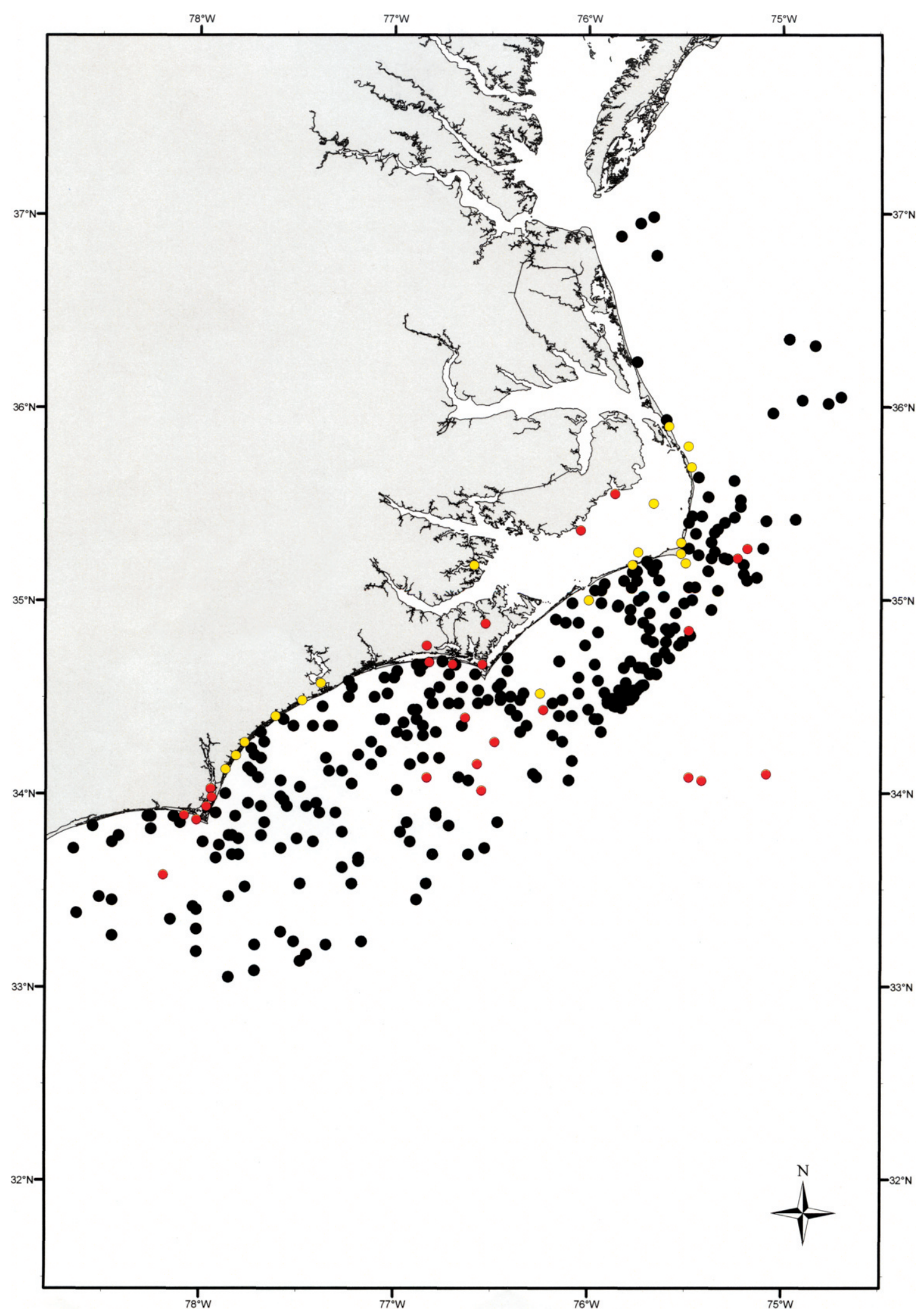

FIG. 1. Collection sites of Atlantic Midshipman by WHOI (black dots), NCDNR (yellow dots) and IMS (red dots). 
sound) between 1983 and 2013; 165 were captured pre 1990, 6 post 1990; depths ranging from $2-109 \mathrm{~m}$. Captures were best in May and September. Sizes ranged: $57-257 \mathrm{~mm}$ SL ( $\overline{\mathrm{x}}$ 163), 63-296 mm TL ( $\overline{\mathrm{x}}$ 184). Largest collections were: 30 specimens at $34^{\circ} 37^{\prime} \mathrm{N}, 74^{\circ} 14^{\prime} \mathrm{W} 11$ September 1945 , depth 20 m (sizes ranged: 85-236 mm SL, $\bar{x} 117,104-196 \mathrm{~mm}$ TL, $\bar{x}$ 133 ) and 51 East of the Knuckle Buoy $34^{\circ} 01^{\prime} \mathrm{N}, 76^{\circ} 38^{\prime} \mathrm{W}$, depth $20 \mathrm{~m}$ (sizes ranged 68-228 mm SL, $\overline{\mathrm{x}} 208 \mathrm{~mm}, 68$ $250 \mathrm{~mm}$ TL, $\overline{\mathrm{x}} 233 \mathrm{~mm}$ ). Formulas to convert SL to TL and TL to SL were: SL to TL $\log y=0.9088 x+0.250, r^{2}=$ 0.9028 , TL to SL $\log \mathrm{y}=0.9934 \mathrm{x}-0.0342, \mathrm{r}^{2}=0.9028$.

Only 11 midshipman of 4,410 fishes were collected in 1972 at the offshore scallop ground fishery $\left(30^{\circ} \mathrm{N}\right.$, $76^{\circ} 35^{\prime} \mathrm{W}$ to $76^{\circ} 55^{\prime} \mathrm{W}$ ) before it collapsed (Schwartz and Porter 1977). Water temperatures ranged $9-33^{\circ} \mathrm{C}$, depths 19-37 m, Atlantic Midshipman sizes ranged 130-140 mm TL. Only two midshipman were captured in Pamlico Sound; one $232 \mathrm{~mm}$ TL at Gull Rock, Wysocking Bay, Pamlico Sound pound net, Hyde County, 1 September 1925 and one (120 mm SL, $32 \mathrm{~mm}$ TL), 29 June 1974, in the North River thoroughfare, Carteret county. Elsewhere Atlantic midshipman were collected from the Cape Fear estuary mouth and upstream for $3 \mathrm{~km}$ between 1972-1978 (Schwartz et al. 1978). Sizes ranged 130$146 \mathrm{~mm} \mathrm{TL}, 27^{\circ} \mathrm{C} 8-27^{\circ}$ ? N oxygen content $3.2-8.0 \mathrm{ppm}$.

$N C D N R$.- Thirty eight Atlantic midshipman were collected by the R/V Dan Moore while trawling offshore NC between 1968-1981. Two were collected in Pamlico Sound. Thirty eight other Atlantic midshipman were collected by fly trawls during the same period. Efforts by the NCDNR netted 76 Atlantic midshipman (69 pre 1990, 7 post 1990. Best collections were made in 1968, 1978 and 1998.

$R / V$ Silver Bay.-Forty-eight Atlantic midshipman were collected trawling offshore from Cape Hatteras to Cape Lookout, mostly in 1959: capture depths were 15$31 \mathrm{~m}$ (Bullis and Thompson 1965).

Gilbert.-In (1968) in his revision of the genus Porichthys reported 16 specimens captured between $34^{\circ} 15^{\prime} \mathrm{N}, 75^{\circ} 12^{\prime} \mathrm{W}$ to $35^{\circ} 10^{\prime} \mathrm{N}, 75^{\circ} 30^{\prime} \mathrm{W}$; at depths 5-62 $\mathrm{m}$.

Miscellaneous. - Coles in Gudger (1913) reported the collection of the first Atlantic midshipman (227 mm TL) in waters at Wreck point in the bight of Cape Lookout in 1910. Fahy (1965) reviewing the commercial trash fishery in North Carolina found several Atlantic midshipman in the catches, but did not mention numbers caught. Gudger (original field notes in my possession) noted 11 specimens captured between 1916 and 1925, primarily in the Beaufort, NC area. Three Atlantic midshipman are known housed in the U.S. National Museum in Washington, DC.

\section{CONCLUSIONS}

A total of 2,910 Atlantic midshipman were collected from North Carolina waters between 1911-2012. All but
15 were caught in the ocean: $2,707(93 \%)$ pre 1990 and $193(4.6 \%)$ post 1990, when ocean waters turned from cool to warm. Today Atlantic midshipman are rarely seen or collected. Overfishing does not explain this disappearance of midshipman. It seems reaction to changing ocean water temperatures influenced the long term decline.

Acknowledgments: R. Brown, L. Duprey, and W. Kramer were instrumental in supplying WHOI trawl survey data. R. Robbins (Florida State University, Gainesville, Florida) provided Gilbert and R/V Silver Bay data. G. Joyner (NCDNR), uncovered data particularly by the R/V Dan Moore and other North Carolina collections. G. Hogue (NCMS) permitted re-examination of the IMS material at Raleigh, NC. J. Miller (Duke Marine Library, Beaufort, NC) found several rare references. B Peierls configured Figure 1. G. Safrit (IMS) produced the SL-TL regression analyses and typed the text.

\section{LITERATURE CITED}

BULLIS, H. R. JR., AND J. R. THOMPSON. 1965. Collections by the exploratory fishing vessels, Oregon, Silver Bay, combat and Pelican made during 1956 in the Southeast Atlantic. U.S. Fish Wild. Serv. SSR-. Fish. 510 p.

CALDWELL, D. R., AND M. C. Caldwell. 1963. Anew toadfish of the genus Porichthys from Carribbean climes. Los Angles County, Mus. Contr. 1-8.

COllette, B. B. 2002. Toadfishes (Batrachoididae) of Pp. 1226-1242 in Carpenter. K. Living Resources of the Western Coastal Atlantic. Vol. 2. Bony Fishes. Pt.1. Acipenseridae to Grammistidae. FAO Spec. Identification guide for fishery purposes. Amer. Soc. Ichtyol. Herpetol. Bull. 5.

FAHY, W. E. 1965a. Report of Trashfish study in North Carolina in 1962. Spec. Sci. Rept. 7. NC Dept. Comm. Fish. 20 p.

FAHY, W. E. 1965b. Report of Trashfish study in North Carolina in 1962. Spec. Sci. Rept. 5. NC Dept. Comm. Fish. 13 p.

GILBERT, C. R. 1968. Western Atlantic Batrachoidid fishes of the genus Porichthys, with three new species. Bull. Mar. Sci. 18(3):679-730.

GUDGER, E. W. 1913. Natural history notes on some common fishes 1910-1911. III. J. Mitch. Soc. pp. 157-172.

HUBBS, C. L., AND L. P. SCHULTZ. 1939. A revision of the toadfish genus Porichthys and related study. Proc. USNM 86(3860): 473-486.

JORDAN, D. S. 1919. New Genera of Fishes. Prod. Acad. Nat. Sci. Phila. 90:342-344.

McCHERAN, J., AND J. FECHHELM. 1998. Fishes of the Gulf of Mexico, Vol. 1. Myxiniformes to Gasterosteiformes Texas Univ. Press, Austin. 112 p.

SCHWARTZ, F. J. 2012. Changes in North Carolina's marine Fish Fauna: good or bad? J. Nor. Car. Acad. Sci. 128(3-4):44-50.

SCHWARTZ, F. J., AND A. F. Chestnut. 1973. Hydrographic Atlas of North Carolina's Estuarine and Marine Waters. UNC Sea Grant Publ. SC-73-12. 132 p.

SCHWARTZ, F. J., AND H. J. PORTER. 1977. Fishes, macroinvertebrates and their integrated Interrelationships with a Calico Scallop bed off North Carolina. Fish. Bull 75(2):427-446.

SCHWARTZ, F. J., W. T. HOGARTH, AND M. P. WEINSTEIN. 1982. Marine and Freshwater fishes of the Cape Fear Estuary, 
North Carolina, and their distribution in relation to environmental factors. Brimleyana 7:17-37.

SCHWARTZ, F. J., ET AL. 1978. An ecological study of fishes and invertebrate macrofauna catalogued of the Cape Fear River water, Carolina Beach inlet, Atlantic Ocean. University Publication, Morehead City, North Carolina. 826 p.
SMITH, H. M. 1907. Fishes of North Carolina. NC Geol. Econ. Surv. $453 \mathrm{p}$.

WiGley, S. C., H. M. McBRIDE, and H. J. McHUGH. 2003. Length-weight relationships for 74 fish species Collected by NESC research vessel bottom trawl surveys 1972-1999. NOAA Tech. Mar. NMFS-NE-17. 26 p. 